\section{Long-term Grazing Effects on Stipa-Bouteloua Prairie Soilst}

\author{
S. SMOLIAK, J. F. DORMAAR, AND A. JOHNSTON
}

Range Ecologist, Soil Scientist, and Range Ecologist, Research Station, Canada Department of Agriculture, Lethbridge, Alberta.

\section{Highlight}

The effects of grazing on Stipa-Bouteloua prairie soils in Alberta were evaluated after 19 years of continuous summer use by sheep at three stocking intensities. Analysis of the soils under the heavy grazing treatment showed lower values for $\mathrm{pH}$ and percent spring moisture but higher values for total carbon (C), alcohol/benzene-extractable $\mathrm{C}$, alkaline-soluble $\mathrm{C}$, polysaccharides, and belowground plant material than the soil under light or no grazing. The results were attributed to changes in amounts and kinds of roots due to species changes caused by grazing and to increased amounts of manure deposited by sheep on fields grazed at a higher intensity. Shallow-rooted species replaced the deeperrooted ones on the drier environment induced by heavy grazing.

Grazing studies have emphasized plant-animal relationships and have usually considered range soils only in relation to damage by erosion. But the kind of vegetation affects and modifies the soil on which it grows (Humphrey, 1962). Hence, changes in vegetation caused by grazing animals should affect and modify soil of grazed fields.

Results of a study of long-term grazing effects on fescue grassland soils (Johnston et al., 1971) showed that very heavy grazing by cattle of range that previously had been lightly grazed changed the color of the Ah horizon from black to dark brown and the $\mathrm{pH}$ from 5.7 to 6.2 , reduced percent organic matter, decreased percent soil moisture, reduced percent total $\mathbf{P}$ but increased available $P$, and increased soil temperature. We suggested that the results reflected increased use of vegetation by cattle and, hence, increased erosion from the more heavily grazed fields.

The purpose of this study was to assess long-term effects of grazing by sheep on Stipa-Bouteloua prairie soils.

\section{Materials and Methods}

The study site was at the Canada Department of Agriculture Research Substation, Manyberries, Alberta, where the vegetation is that

${ }^{1}$ Received May 3, 1971. of the mixed prairie (Coupland, 1961), the climate is semiarid, and the annual precipitation averages about $31 \mathrm{~cm}$. The soil is a member of the Brown Subgroup of the Solod Great Group of the Solonetzic Order. It has a leached Ae horizon and a strongly columnar B horizon. Numerous shallow, eroded pits are present throughout the area. Profile description is:

\begin{tabular}{|c|c|c|}
\hline $\mathrm{Ah}$ & $0-10 \mathrm{~cm}$ & $\begin{array}{l}\text { Brown (10YR } 4 / 3- \\
5 / 3 \text {, dry), loam to } \\
\text { sandy loam, weak } \\
\text { platy to granular. }\end{array}$ \\
\hline $\mathrm{Ae}$ & $10-14 \mathrm{~cm}$ & $\begin{array}{l}\text { Grayish to pale } \\
\text { brown (10YR } 5 / 2- \\
6 / 3, \text { dry), loam, } \\
\text { platy. }\end{array}$ \\
\hline Bnt & $14-27 \mathrm{~cm}$ & $\begin{array}{l}\text { Pale brown (10YR } \\
6 / 3 \text {, dry), clay } \\
\text { loam to sandy } \\
\text { clay loam, round- } \\
\text { topped columnar. }\end{array}$ \\
\hline $\mathbf{c a}$ & At $27 \mathrm{~cm}$ & $\begin{array}{l}\text { Light brownish } \\
\text { gray (10YR } 6 / 2 \text {, } \\
\text { dry), massive. }\end{array}$ \\
\hline
\end{tabular}

In 1950 the study site was divided into three fields. Prior to 1950 the area was lightly grazed by sheep. From 1951 these fields were grazed by ewes with lambs from about May 1 to November 1 each year. The grazing trcatments were: light, 2.5 hectares per animal unit month (AUM); moderate, 2.0 ha/AUM; and heavy, 1.7 ha/AUM. A nearby exclosure, protected since 1928, served as an ungrazed control. Percentage basal area of vegetation was determined by the vertical point method in August 1950 and 1969.

In April 1970, 10 random core samples $(10 \mathrm{~cm}$ diameter $)$ were obtained from the $\mathrm{Ah}$ horizon of the soil profile from each grazed field and from the ungrazed exclosure. After the samples were air-dried and ground to pass a $1-\mathrm{mm}$ screen, their dry colors were rated according to the Munsell (1954) notation. Moisture content was determined at time of sampling. Moisture retention, expressed as percent of airdry basis (U.S. Salinity Laboratory Staff, 1954), was determined at 1, 5, and 15 bar, and at 100, 200, 300, and 500 mbar. (Moisture retention at 15 bar and at 200 mbar was taken as an index of permanent wilting percentage and field capacity, respectively.) Neutral $\mathrm{NH}_{4} \mathrm{OAc}$ was used for the displacement of exchangeable cations and NaOAc solution at $\mathrm{pH} 8.2$ for the determination of the cation exchange capacity (U.S. Salinity Laboratory Staff, 1954). Exchange acidity was determined with $\mathrm{BaCl}_{2}$ triethanolamine at $\mathrm{pH} 8.1$ (Black, 1965b). Soil $\mathrm{pH}$ was measured in $0.01 \mathrm{M}$ $\mathrm{CaCl}_{2}$. Total carbon $(\mathrm{C})$, nitrogen $(\mathrm{N})$, nitrates $\left(\mathrm{NO}_{3}\right)$ phosphorus $(\mathrm{P})$, and $\mathrm{NaHCO}_{3}$-soluble $\mathrm{P}$ were determined as outlined by Black (1965b). Polysaccharide content was determined using anthrone (Brink et al., 1960). Two separate fractions of organic matter, onc that is soluble in alcohol:benzene (1:1 EtOH: $\mathrm{C}_{6} \mathrm{H}_{6}$ ) and one that is soluble in alkaline solution $(0.1 \mathrm{~N} \mathrm{NaOH})$. were determined. The first fraction, which included the fats, resins, waxes, and humic substances, is, henceforth, referred to as alcohol/ benzene-extractable $\mathrm{G}$ and the second fraction as the alkaline-soluble C. An additional 10 samples per field were analyzed for bulk density (U.S. Salinity Laboratory Staff, 1954) and particle size (Black, 1965a). 
Table 1. Basal arca (\%) of vegetation on study areas at Manyberries, 1950 and 1969.*

\begin{tabular}{|c|c|c|c|c|c|}
\hline \multirow[b]{2}{*}{ Species } & \multirow{2}{*}{$\begin{array}{l}\text { Study area } \\
\text { in } 1950\end{array}$} & \multicolumn{4}{|c|}{$\begin{array}{l}\text { Study areas in } 1969 \text { by } \\
\text { grazing treatments }\end{array}$} \\
\hline & & Ungrazed & Light & Moderate & Heavy \\
\hline Blue grama & 2.0 & 0.3 & 2.4 & 2.8 & 3.6 \\
\hline Needle-and-thread & 0.6 & 2.2 & 1.3 & 1.2 & 0.5 \\
\hline Western wheatgrass & 1.4 & 1.3 & 1.7 & 1.2 & 0.7 \\
\hline Other grasses & 1.3 & 1.4 & 1.6 & 1.5 & 1.1 \\
\hline Low sedge & 0.9 & 0.4 & 0.5 & 0.8 & 1.1 \\
\hline Forbs and shrubs & 0.5 & 0.4 & 0.7 & 0.9 & 0.4 \\
\hline Little club moss & 7.1 & 9.6 & 18.7 & 22.6 & 26.0 \\
\hline
\end{tabular}

* Each value is the mean of 4200 points.

A respiratory study was conducted $^{2}$ on soils from the heavilygrazed and ungrazed fields. Duplicate $100 \mathrm{~g}$ samples of soil were placed in a respiration apparatus and incubated at $28 \mathrm{C}$ with moisture maintained at 200 mbar or about $18 \%$. Evolved $\mathrm{CO}_{2}$ was absorbed in approximately $1 \mathrm{~N} \mathrm{NaOH}$, and amounts were determined by differential titration using a Beckman automatic titrator. Glucose, equivalent to $2000 \mathrm{ppm} \mathrm{C}$, was added to half of the samples. The general procedure is described by Chandra and Bollen (1960) and by Bollen and $\mathrm{Ku}$ (1961). Results were plotted as accumulative difference in $\mathrm{C}$ released $(\mathrm{mg} / 100 \mathrm{~g})$ as $\mathrm{CO}_{2}$ from glucose-treated and untreated soil.

Ten soil cores, $6.5 \times 60 \mathrm{~cm}$, were obtained from each field, and amounts of belowground plant material by $15 \mathrm{~cm}$ increments were measured. Hot-water-soluble carbohydrate content of belowground plant parts from the upper $15 \mathrm{~cm}$ increment of the soil profile was determined (Deriaz, 1961) .

\section{Results}

\section{Vegetation}

Species composition of the vegetation changed as a result of grazing. Percentage basal area of blue grama (Bouteloua gracilis (HBK.)

\footnotetext{
${ }^{2}$ We are grateful to Dr. J. L. Neal, Soil Microbiologist, who conducted the
} respiration study reported herein.
Lag.), low sedge (Carex eleocharis Bailey), and little club-moss (Selaginella densa Rydb.) increased with increased grazing pressure whereas that of needle-and-thread (Stipa comata Trin. and Rupr.) and western wheatgrass (Agropyron smithii Rydb.) decreased (Table 1).

Weight of belowground plant parts in the upper $15 \mathrm{~cm}$ and in the $0-60 \mathrm{~cm}$ increments of the soil profile increased significantly as grazing pressure increased, did not differ significantly in the 15-30 and $30-45 \mathrm{~cm}$ depths, but decreased significantly at the $45-60 \mathrm{~cm}$ depth (Table 2). Water-soluble carbohydrate content of belowground plant parts from the upper $15 \mathrm{~cm}$ increment was significantly greater under light or no grazing than under moderate or heavy grazing.

Table 2. Weight and water-soluble carbohydrate content of belowground plant parts of study areas grazed at various rates for the previous 19 years at Manyberries, 1970.*

\begin{tabular}{crrrr}
\hline \hline \multirow{2}{*}{$\begin{array}{c}\text { Measurement } \\
\text { and depth }\end{array}$} & \multicolumn{5}{c}{ Grazing treatments } \\
\cline { 2 - 5 } Belowground plant biomass & $(\mathrm{kg} / \mathrm{ha})$ & Light & Moderate & Heavy \\
\hline $0-15 \mathrm{~cm}$ & $14,955 \mathrm{a}$ & $16,163 \mathrm{ab}$ & $18,946 \mathrm{~b}$ & $24,038 \mathrm{~b}$ \\
$15-30 \mathrm{~cm}$ & $2,681 \mathrm{a}$ & $2,663 \mathrm{a}$ & $2,413 \mathrm{a}$ & $2,529 \mathrm{a}$ \\
$30-45 \mathrm{~cm}$ & $2,120 \mathrm{a}$ & $2,495 \mathrm{a}$ & $1,877 \mathrm{a}$ & $2,299 \mathrm{a}$ \\
$45-60 \mathrm{~cm}$ & $1,330 \mathrm{a}$ & $861 \mathrm{~b}$ & $457 \mathrm{~b}$ & $599 \mathrm{~b}$ \\
Total & $21,086 \mathrm{a}$ & $22,182 \mathrm{a}$ & $23,693 \mathrm{a}$ & $29,465 \mathrm{~b}$
\end{tabular}

Water-soluble carbohydrate content of roots $(\mathrm{mg} / \mathrm{g}$ )
$0-15 \mathrm{~cm}$
22.0 a
$21.4 \mathrm{a}$
$17.6 \mathrm{~b}$

$14.8 \mathrm{~b}$

* Each value is the mean of two determinations on each of ten samples. Means in the same row followed by the same letter do not differ significantly at the $5 \%$ level (Duncan's multiple range test). 
Table 3. Characteristics of Ah horizon of soil from the study areas grazed at various rates for the previous 19 years at Manyberries, 1970.*

\begin{tabular}{|c|c|c|c|c|c|c|c|c|}
\hline \multirow[b]{2}{*}{ Characteristic } & \multicolumn{8}{|c|}{ Grazing treatments } \\
\hline & \multicolumn{2}{|c|}{ Ungrazed } & \multicolumn{2}{|c|}{ Light } & \multicolumn{2}{|c|}{ Moderate } & \multicolumn{2}{|c|}{ Heavy } \\
\hline Color (dry) & \multicolumn{2}{|c|}{ 10YR 4/3 } & \multicolumn{2}{|c|}{10 YR $5 / 3$} & \multicolumn{2}{|c|}{10 YR $5 / 3$} & \multicolumn{2}{|c|}{ 10YR $5 / 5$} \\
\hline \\
\hline sand $(\%)$ & 53 & $\mathrm{a}$ & 51 & $\mathbf{a}$ & 51 & a & 52 & $\mathrm{a}$ \\
\hline clay $(\%)$ & 17 & $\mathbf{a}$ & 16 & $\mathrm{a}$ & 15 & $\mathbf{a}$ & 15 & $\mathrm{a}$ \\
\hline \multicolumn{9}{|l|}{ Soil moisture } \\
\hline April $1970(\%)$ & 19.0 & $\mathrm{a}$ & 15.1 & $\mathrm{~b}$ & 15.0 & $\mathrm{~b}$ & 11.1 & c \\
\hline 200 mbar tension $(\%)$ & 18.4 & $\mathbf{a}$ & 17.4 & $\mathbf{a}$ & 17.2 & $\mathbf{a}$ & 17.0 & a \\
\hline 15 bar tension $(\%)$ & 7.3 & $\mathbf{a}$ & 6.7 & a & 6.1 & $\mathbf{a}$ & 6.5 & a \\
\hline Bulk density $\left(\mathrm{g} / \mathrm{cm}^{3}\right)$ & 1.27 & $\mathbf{a}$ & 1.25 & $\mathbf{a}$ & 1.28 & $\mathbf{a}$ & 1.28 & $\mathrm{a}$ \\
\hline Total C (\%) & 1.10 & $\mathbf{a}$ & 1.15 & $\mathrm{ab}$ & 1.16 & $a b$ & 1.38 & $\mathrm{~b}$ \\
\hline Total N (\%) & 0.12 & $\mathbf{a}$ & 0.12 & $\mathbf{a}$ & 0.11 & $\mathbf{a}$ & 0.12 & $\mathbf{a}$ \\
\hline $\mathrm{NO}_{3}-\mathrm{N}(\mu \mathrm{g} / \mathrm{g})$ & 0.53 & $\mathrm{a}$ & 0.68 & $\mathrm{a}$ & 0.78 & $\mathbf{a}$ & 1.00 & $\mathrm{a}$ \\
\hline $\mathrm{C} / \mathrm{N}$ ratio & 9.1 & $\mathrm{a}$ & 9.9 & $\mathrm{~b}$ & 10.4 & $\mathrm{~b}$ & 10.3 & $\mathrm{~b}$ \\
\hline $\begin{array}{l}\text { Alcohol/benzene- } \\
\text { extractable } \mathbf{C}(\%)\end{array}$ & \multicolumn{2}{|c|}{0.054 a } & \multicolumn{2}{|c|}{$0.065 \mathrm{a}$} & \multicolumn{2}{|c|}{$0.078 \mathrm{~b}$} & \multicolumn{2}{|c|}{$0.079 \mathrm{~b}$} \\
\hline $\begin{array}{c}\text { Alkaline-soluble } \mathrm{C} \\
(\% \text { of total } \mathrm{C})\end{array}$ & 15.5 & $\mathbf{a}$ & 17.2 & $\mathrm{~b}$ & 18.0 & $\mathrm{bc}$ & 19.5 & c \\
\hline Total P $(\%)$ & 0.035 & $a$ & 0.035 & $a$ & 0.032 & $a$ & 0.035 & 5 \\
\hline Available $\mathrm{P}(\mu \mathrm{g} / \mathrm{g})$ & 2.5 & $\mathrm{a}$ & 2.6 & $\mathbf{a}$ & 2.5 & $\mathbf{a}$ & 2.3 & a \\
\hline Soil $p \mathrm{H}\left(\mathrm{CaCl}_{2}\right)$ & 6.4 & $\mathrm{a}$ & 6.3 & $a b$ & 6.0 & b & 5.8 & $\mathrm{~b}$ \\
\hline \multicolumn{9}{|l|}{ Exchangeable cations } \\
\hline $\mathrm{Ca}$ (meq/100 g) & 8.57 & $\mathrm{a}$ & 5.84 & $\mathrm{~b}$ & 5.04 & $\mathbf{b}$ & 4.75 & $\mathrm{~b}$ \\
\hline $\mathrm{K}$ (meq/100 g) & 0.70 & $\mathbf{a}$ & 0.74 & $\mathbf{a}$ & 0.65 & $\mathbf{a}$ & 0.68 & $\mathbf{a}$ \\
\hline $\mathrm{Na}$ (meq/100 g) & 0.31 & $\mathrm{a}$ & 0.22 & $\mathrm{~b}$ & 0.23 & $\mathrm{~b}$ & 0.20 & $\mathrm{~b}$ \\
\hline $\begin{array}{l}\text { Exchangeable acidity } \\
\quad(\mathrm{pH} 8.1 \text { (meq/100 g) }\end{array}$ & 2.60 & $\mathbf{a}$ & 2.72 & $\mathbf{a}$ & 2.92 & $\mathbf{a}$ & 3.40 & b \\
\hline CEC (meq/100 g) & 15.1 & $\mathrm{a}$ & 13.7 & $\mathrm{a}$ & 13.7 & $\mathbf{a}$ & 13.2 & $\mathrm{a}$ \\
\hline
\end{tabular}

* Values are means of two determinations on each of ten samples. Means in the same row followed by the same letter do not differ significantly at the 5\% level (Duncan's multiple range test).

The accumulative difference between the $\mathrm{CO}_{2}$ released by the glucose-treated and the untreated soil was greater for soil samples from the heavily grazed than from the ungrazed fields after 10 days (Fig. 1).

With few exceptions, correlation coefficients among various soil factors were highly significant (Table 4).

Amounts of elements removed by animals from soil of the grazing fields were low in relation to total amounts in the profile. The estimated amounts of elements removed annually were $0.3,0.5$, and able $\mathbf{P}$ and $\mathrm{N}$ content. But a number of significant changes did occur. The $\mathrm{pH}$ changed from 6.4 under no grazing to 5.8 under heavy grazing. Total $\mathrm{C}$, alcohol/benzeneextractable $\mathrm{C}$, alkaline-soluble $\mathrm{C}$, and polysaccharides all increased with increasing grazing pressure. Most of these soil characteristics were significantly correlated $(\mathrm{P}<$ 0.05 , Table 4). However, the correlation of total $\mathrm{G}$ content with alkaline-soluble $\mathrm{C}$ was low and not significant. It was likely that the increase did not occur simultaneously, that is, the total $\mathrm{C}$ increased relatively less than did the alkaline-soluble $\mathrm{C}$, when considered as percent in the soil. Usually a negative relationship exists between alkaline-soluble $\mathrm{C}$ and exchangeable Ca; however, in this study the relationship was not significant.

Although data obtained in laboratory respirometers, in which soil was wetted and treated with glucose, cannot be extrapolated to field conditions, the effect of different grazing intensities on potential in vitro decomposition rates can be studied using this technique. The greater difference in $\mathrm{CO}_{2}$ release between untreated and glucose-treated soils in heavily grazed than in ungrazed areas was expected because of the greater amount of total belowground plant biomass (Table 2), total $\mathrm{C}, \mathrm{NO}_{3}-\mathrm{N}$ (Table 3), and the polysaccharide content of belowground plant materials in the heavily grazed areas than in the ungrazed ones.

Soil compaction on the fields grazed by sheep was not a problem on these generally dry soils. There were no differences in bulk density of soil from grazed or ungrazed fields. Soil compaction by trampling has been reported in other studies (Humphrey, 1962).

The increased weight of belowground plant material on the heavily grazed field at depths to $15 \mathrm{~cm}$ reflects changes in the vegetative cover (Table 2 and 1). Deeperrooted needle-and-thread and western wheatgrass were replaced by shallow-rooted little club-moss and 


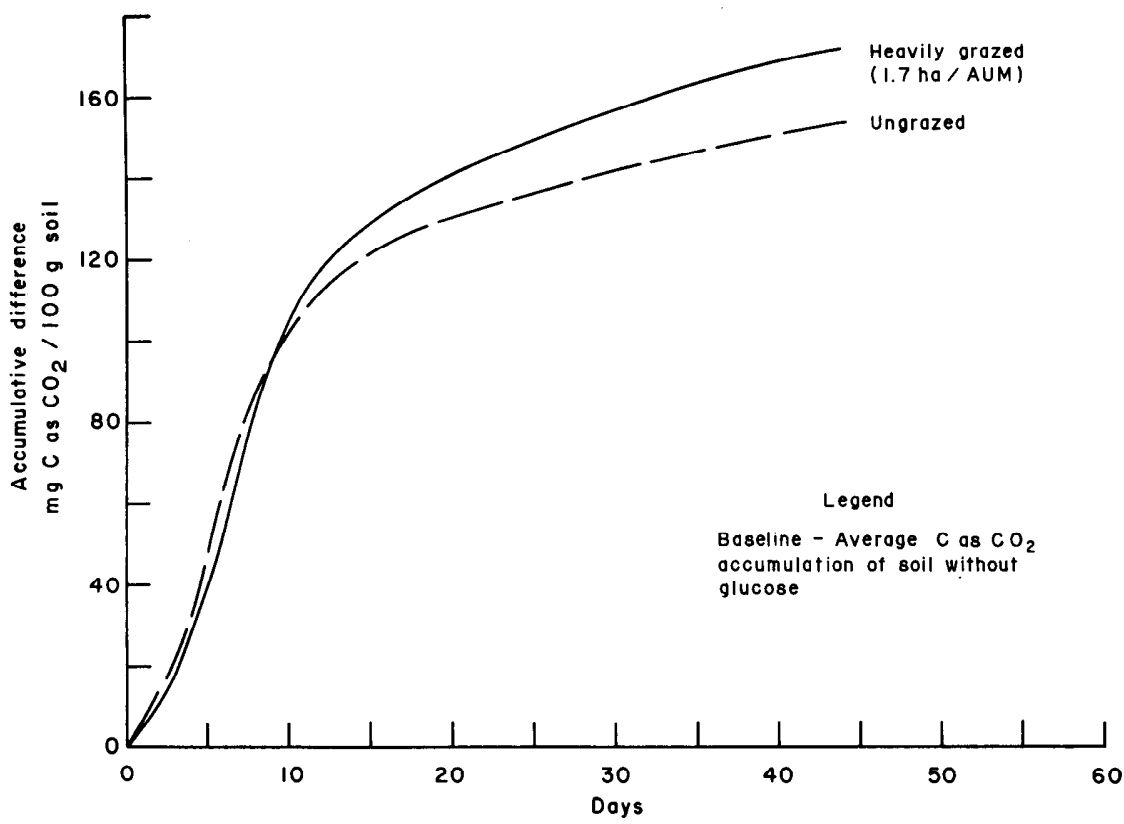

FIG. 1. Potential accumulative decomposition of soil organic matter from the ungrazed enclosure and from a field heavily grazed for the previous 19 years, Manyberries, 1970.

blue grama. Coupland and Johnson (1965) have shown that depth of rooting of blue grama averaged 19 $\mathrm{cm}$ less than needle-and-thread and $29 \mathrm{~cm}$ less than western wheatgrass. Both blue grama and little clubmoss have roots near the soil surface and, hence, are well adapted to conditions where moisture during the growing scason is confined to the upper portion of the soil profile. Under heavy grazing, soil moisture in spring was significantly lower than under no grazing. Beebe and Hoffman (1968) found that where heavy grazing had significantly reduced the vegetation cover both soil surface temperatures and evaporation rates increased. The greater concentration of roots at the $45-60$ $\mathrm{cm}$ level on the ungrazed site than on the grazed fields shows the effect, noted also by Lorenz and Rogler (1967), of herbage removal by grazing., As intensity of grazing increased, water-soluble carbohydrate content of the roots decreased. Kinsinger and Hopkins (1961), Jameson (1963), and Troughton (1957:56) obtained similar results.

The addition of feces and urine may add growth-promoting substances to the soil and thereby aid root growth (Jameson, 1963). Since these substances would generally be present at shallow depths (Kononova, 1966:340), one would expect the proportion of roots at this depth to increase as intensity of grazing increased (Table 2). Kononova (1966:340) concluded that as manure enriches the soil it increases the content of mobile forms of humic acids in the composition of humus. Also, root production by plants is vigorous in the presence of water-soluble humus substances.

This study indicates that continued heavy grazing of Stipa-Bouteloua prairie not only changes the vegetative cover but also some of the soil properties in the $\mathrm{Ah}$ horizon. Part of the changes in the soil were induced through a reduction

Table 4. Correlation coefficients to show relationships among environmental factors, Manyberries, $1970(n=40)$.

\begin{tabular}{|c|c|c|c|c|c|c|c|c|c|c|c|c|c|}
\hline & & 1. & 2. & 3. & 4. & 5. & 6. & 7. & 8. & 9. & 10. & 11. & 12. \\
\hline 1. & Sand in $\mathrm{Ah}(\%)$ & 1.000 & & & & & & & & & & & \\
\hline 2. & Clay in $\mathrm{Ah}(\%)$ & $-0.628 * \star$ & 1.000 & & & & & & & & & & \\
\hline 3. & Soil moisture - 200 mbar tension $(\%)$ & $-0.795 * *$ & $0.792 * \star$ & 1.000 & & & & & & & & & \\
\hline 4. & So11 moisture - 15 bar tension (\%) & $-0.596 * *$ & $0.724 * \star$ & $0.865 * \star$ & 1.000 & & & & & & & & \\
\hline 5. & $C(\%)$ & $-0.741 * \star$ & $0.551 * \star$ & $0.751 * \star$ & $0.672 * \star$ & 1.000 & & & & & & & \\
\hline 6. & $N(\%)$ & $-0.633 * *$ & $0.542 \star *$ & $0.737 * *$ & $0.692 \star \star$ & $0.933 * \star$ & 1.000 & & & & & & \\
\hline 7. & Alcohol/benzene-extractable C (\%) & $-0.671 * *$ & 0.292 & $0.560 * \star$ & $0.374 *$ & $0.752 * \star$ & $0.604 \star \star$ & 1.000 & & & & & \\
\hline 8. & Polysaccharides (mg/100 g) & $-0.691 * *$ & $0.410 * *$ & $0.689 * \star$ & $0.702 \star \star$ & $0.886 * \star$ & $0.841 * *$ & $0.711 * *$ & 1.000 & & & & \\
\hline 9. & Alkaline-soluble $\mathrm{C}$ (\% of total $\mathrm{C}$ ) & -0.113 & -0.029 & -0.020 & -0.024 & 0.122 & -0.018 & 0.243 & 0.220 & 1.000 & & & \\
\hline 10. & Total P ( $)$ & $-0.636 * *$ & $0.713 * \star$ & $0.810 * *$ & $0.779 * \star$ & $0.726 * *$ & $0.776 * *$ & $0.366 *$ & $0.615 * *$ & -0.090 & 1.000 & & \\
\hline 11. & CEC (meq/100 g) & $-0.521 * \star$ & $0.576 \star \star$ & $0.737 * *$ & $0.789 * \star$ & $0.713 * \star$ & $0.821 * \star$ & $0.317 *$ & $0.689 * *$ & -0.066 & $0.783 * \star$ & 1.000 & \\
\hline 12. & Exchangeable cations - Ca (meq/100 g) & -0.279 & $0.603 * *$ & $0.687 * *$ & $0.787 \star \star$ & $0.341 *$ & $0.431 * *$ & 0.061 & $0.407 * \star$ & -0.213 & $0.581 * *$ & $0.601 * *$ & 1.000 \\
\hline 13. & Exchangeable cations $-\mathrm{K}$ (meq/100 g) & $-0.702 * \star$ & $0.707 * *$ & $0.812 \star *$ & $0.885 * \star$ & $0.698 * *$ & $0.628 * *$ & $0.503 * *$ & $0.694 * *$ & 0.054 & $0.721 * *$ & $0.678 * \star$ & $0.615 * *$ \\
\hline
\end{tabular}


in rooting depth resulting from species change in which shallow-rooted species replaced the deep-rooted ones, and part was due to increased amounts of manure deposited by sheep on the more heavily grazed fields.

\section{Literature Cited}

BeEbe, J. D., and G. R. Hoffman. 1968. Effects of grazing on vegetation and soils in southeastern South Dakota. Amer. Midl. Natur. 80:96110.

Black, C. A. 1965a. Methods of soil analysis. Part 1. Physical and minerological properties. Agronomy 9: 1-770.

Black, C. A. 1965b. Methods of soil analysis. Part 2. Chemical and microbiological properties. Agronomy 9:771-1572.

Bollen, W. B., and K. C. Ku. 1961. Microbial decomposition and nitrogen availability of reacted sawdust, bagasse, and coffee grounds. Agr. Food Chem. 9:9-15.
Brink, R. H., P. Dubach, and D. L. LYNCH. 1960. Measurements of carbohydrates in soil hydrolysates with anthrone. Soil Sci. 89:157-166.

Chandra, P., ANd W. B. Bollen. 1960. Effect of wheat straw, nitrogenous fertilizers, and carbon-to-nitrogen ratio on organic decomposition in a subhumid soil. Agr. Food Chem. 8: 19-24.

Coupland, R. T. 1961. A reconsideration of grassland classification in the Northern Great Plains of North $\Lambda$ merica. J. Ecol. 49:135-167.

Coupland, R. T., and R. E. Johnson. 1965. Rooting characteristics of native grassland species in Saskatchewan. J. Ecol. 53:475-507.

Deriaz, R. E. 1961. Routine analysis of carbohydrates and lignin in herbage. J. Sci. Food Agr. 12:152-160.

Humphrey, R. R. 1962. Range ecology. The Ronald Press Co., New York, N.Y. 234 p.

JAMEson, D. A. 1963. Responses of individual plants to harvesting. Bot. Rev. 29:532-594.

Johnston, A., J. F. DormaAr, AND S. SMOLIAK. 1971. Long-term grazing effects on fescue grassland soils. J Range Manage. 24:185-188.

Kinsinger, F. E., and H. H. Hopkins. 1961. Carbohydrate content of underground parts of grasses as affected by clipping. J. Range Manage. 14: 9-12.

Kononova, M. M. 1966. Soil organic matter. Pergamon Press, New York, N.Y. 544 p.

Lorenz, R. J., AND G. $\Lambda$. Rogler. 1967. Grazing and fertilization affect root development of range grasses. J. Range Manage. 20:129132.

Munsell Soil Color Charts. 1954. Munsell Color Co. Inc., Baltimore, Md. Loose-leaf. np.

Troughton, A. 1957. The underground organs of herbage grasses. Commonwealth Bur. Pastures and Field Crops Bull. 44. 163 p.

United States Salinity Laboratory StAfF. 1954. Diagnosis and improvement of saline and alkali soils. U.S. Dep. Agr. Handbook 60. Government Printing Office, Washington, D.C. 160 p. 